\title{
Effect of pH on the Chemical Composition and Structure-Function Relationships of Cheddar Cheese ${ }^{1}$
}

\author{
A. J. Pastorino, C. L. Hansen, and D. J. McMahon \\ Western Dairy Center \\ Department of Nutrition and Food Sciences \\ Utah State University, Logan 84322
}

\section{ABSTRACT}

The objectives of this study were to determine the effect of $\mathrm{pH}$ on chemical, structural, and functional properties of Cheddar cheese, and to relate changes in structure to changes in cheese functionality. Cheddar cheese was obtained from a cheese-production facility and stored at $4^{\circ} \mathrm{C}$. Ten days after manufacture, the cheese was cut into blocks that were vacuum-packaged and stored for $4 \mathrm{~d}$ at $4^{\circ} \mathrm{C}$. Cheese blocks were then highpressure injected one, three, or five times with a $20 \%$ (wt/wt) glucono- $\delta$-lactone solution. Successive injections were performed $24 \mathrm{~h}$ apart. Cheese blocks were then analyzed after $40 \mathrm{~d}$ of storage at $4^{\circ} \mathrm{C}$. Acidulant injection decreased cheese $\mathrm{pH}$ from 5.3 in the uninjected cheese to 4.7 after five injections. Decreased pH increased the content of soluble calcium and slightly decreased the total calcium content of cheese. At the highest level, injection of acidulant promoted syneresis. Thus, after five injections, the moisture content of cheese decreased from 34 to $31 \%$, which resulted in decreased cheese weight. Lowered cheese $\mathrm{pH}, 4.7 \mathrm{com}$ pared with 5.3, also resulted in contraction of the protein matrix. Acidulant injection decreased cheese hardness and cohesiveness, and the cheese became more crumbly. The initial rate of cheese flow increased when $\mathrm{pH}$ decreased from 5.3 to 5.0, but it decreased when cheese $\mathrm{pH}$ was further lowered to 4.7. The final extent of cheese flow also decreased at $\mathrm{pH}$ 4.7. In conclusion, lowering the $\mathrm{pH}$ of Cheddar cheese alters protein interactions, which then affects cheese functionality. At $\mathrm{pH}$ greater than 5.0, calcium solubilization decreases protein-to-protein interactions. In contrast, at $\mathrm{pH}$ lower than 5.0, the acid precipitation of proteins overcomes the opposing effect caused by increased calcium solubilization and decreased calcium content of cheese, and protein-to-protein interactions increase.

Received February 20, 2003.

Accepted April 2, 2003.

Corresponding author: D. J. McMahon; e-mail: djm@cc.usu.edu.

${ }^{1}$ Contribution number 7530 of the Utah Agricultural Experiment Station. Approved by the director.

(Key words: calcium, high-pressure injection, protein matrix, syneresis)

\section{INTRODUCTION}

A review of the literature on the effect of $\mathrm{pH}$ on cheese properties shows that considerable research has been done on this topic (e.g., Keller et al., 1974; Creamer et al., 1988; Kiely et al., 1992; Marchesseau et al., 1997; Ramkumar et al., 1997, 1998; Kindstedt et al., 2001; Watkinson et al., 2001). The effect of pH has not only been studied in cheese but also in milk and casein systems. In this regard, the most significant effect of decreased $\mathrm{pH}$ is to promote mineral solubilization (Visser et al., 1986; van Hooydonk et al., 1986; Dalgleish and Law, 1989; Kiely et al., 1992; Le Graët and Gaucheron, 1999) and casein dissociation from casein micelles (Roefs et al., 1985; van Hooydonk et al., 1986; Dalgleish and Law, 1988), both of which alter milk properties by affecting the extent and nature of protein interactions. Knowing how $\mathrm{pH}$ affects the properties of milk and casein micelles has provided a basis for understanding its effect on cheese. However, researchers have encountered a major limitation in that modifying cheese $\mathrm{pH}$ causes changes in other chemical parameters of cheese (Lawrence et al., 1983; Lucey and Fox, 1993). This makes it difficult to separate the effect of $\mathrm{pH}$ from that of changes in total and soluble calcium content, moisture content, extent and pattern of proteolysis, and their interactions. As a result, and despite the extensive work already done, some of the fundamental questions about the independent effect of $\mathrm{pH}$, or that of calcium, and which one is predominant, and under which conditions remain unanswered.

In trying to overcome the limitation of confounding effects, alternative methods that may allow for independently modifying the $\mathrm{pH}$ of cheese could be applied. Ramkumar et al. $(1997,1998)$ added glucono- $\delta$-lactone to shredded cheese, while Kindstedt et al. (2001) exposed shredded cheese to either ammonia or acetic acid vapors to modify cheese $\mathrm{pH}$. However, this requires shredding of the cheese, which limits the analysis of textural properties. An alternative to this approach is 
to modify the $\mathrm{pH}$ of cheese by high-pressure injecting a concentrated solution of acidulant into cheese blocks, a method previously used for modifying other chemical parameters of cheese (Pastorino et al., 2003a, 2003b). This method for modifying cheese $\mathrm{pH}$ allows for a more comprehensive study that includes changes in chemical composition, structure, and textural properties of cheese. The objectives of the present research were then to determine the effect of $\mathrm{pH}$ on the chemical, structural, and functional properties of Cheddar cheese, and to relate changes in structure to changes in cheese functionality.

\section{MATERIALS AND METHODS}

\section{Cheese}

A 19-kg block of Cheddar cheese was obtained from a cheese-production facility and stored at $4^{\circ} \mathrm{C}$. Ten days after manufacture, the cheese was cut into 0.4 to 0.5 $\mathrm{kg}$ blocks $(\sim 5 \times 9 \times 6 \mathrm{~cm})$ that were vacuum packaged and stored for an additional $4 \mathrm{~d}$ at $4^{\circ} \mathrm{C}$ before injection.

\section{Cheese Injection}

Cheese was high-pressure injected one, three, or five times with a $20 \%$ (wt/wt) glucono- $\delta$-lactone solution as described by Pastorino et al. (2003a). A two-stage homogenizer served as the pump for injection, and solution exited the system at high speed through a multinozzle injection head. Pressure of injection was set at $17 \mathrm{MPa}$, and the burst duration was set to $1 \mathrm{~s}$, which was observed to give an injectate penetration depth of 1 to $3 \mathrm{~cm}$. Successive injections were performed $24 \mathrm{~h}$ apart and according to an injection pattern of $1 \times 1 \mathrm{~cm}$ applied to two opposite sides of the cheese block. After injection, cheese blocks were blotted with paper towels, weighed, vacuum packaged, and then stored for an additional $40 \mathrm{~d}$ at $4^{\circ} \mathrm{C}$ to allow uniform distribution of injectate throughout the cheese, before analysis (Pastorino, 2002).

\section{Chemical Composition}

Fat content was determined using a modified Babcock method (Richardson, 1985), moisture content by using the vacuum oven AOAC method 926.08 (1990), and sodium chloride according to AOAC (1990) method 971.19 (model 926 salt analyzer; Corning, Medfield, MA). Protein content was determined by measuring total nitrogen content (Kjeldahl method) and multiplying by 6.38 . Total and soluble calcium content was determined by inductively coupled plasma-atomic emission spectroscopy (US Environmental Protection Agency, 1992). To determine soluble calcium, cheese samples $(5 \mathrm{~g})$ were blended with $50 \mathrm{~g}$ of water using a hand-held, high-speed homogenizer, and transferred to a beaker. The blending container was then rinsed with water $(150 \mathrm{~g})$, and the water transferred to the beaker. After standing for $20 \mathrm{~min}$, the solution was filtered through Whatman \#42 filter paper. The filtrate was then analyzed for calcium content. Bound calcium was estimated as the difference between the total and soluble calcium content, most of which would be bound to proteins either directly or indirectly through the formation of insoluble complexes. A pH meter (model 520A, Orion Research Inc., Boston, MA), with a glass probe (spear combo, Corning), was used for determining cheese $\mathrm{pH}$, which was measured by taking a cheese sample from the cheese block and inserting the $\mathrm{pH}$ probe into the cheese. Proteolysis was determined by measuring NPN. Cheese samples ( $3 \mathrm{~g}$ ) were blended with $40 \mathrm{ml}$ of TCA (12\% wt/wt) using a hand-held, highspeed homogenizer. After standing for $30 \mathrm{~min}$, the solution was filtered through Whatman \#42 filter paper, and nitrogen content in the filtrate measured by Kjeldahl method.

\section{Scanning Electron Microscopy}

Cheese samples (approximately $1 \times 1 \times 10 \mathrm{~mm}$ ) of the uninjected cheese and cheese injected five times were taken and fixed in fresh $2 \%$ glutaraldehyde solution at room temperature, and then stored at $4^{\circ} \mathrm{C}$. After refrigerated storage, the samples were processed according to McManus et al. (1993), but as modified by Pastorino et al. (2003a). Thus, samples were frozen in liquefied Freon 22, transferred to liquid nitrogen, cryofractured perpendicular to their long axis, and thawed in $2 \%$ glutaraldehyde. They were then dehydrated in a graded ethanol series followed by fat extraction. After overnight storage, the samples were rehydrated, and washed with sodium cacodylate buffer, $\mathrm{pH}$ 7.2. The samples were then postfixed with a solution containing osmium tetroxide and potassium ferrocyanate, and staining enhanced by a tannic acid solution in cacodylate buffer. After postfixing, the samples were washed with distilled water, dehydrated in a graded ethanol series, and air-dried. Samples were then coated with a gold-iridium mix. After coating, samples were viewed in a field emission scanning electron microscope operated at $3 \mathrm{kV}$. Images, at $1500 \times$ magnification, from eight fields were recorded on film and digitally. Fields were randomly selected from areas of the sample that exhibited good quality planes of fracture.

\section{Image Analysis}

Digital images of electron micrographs were uploaded into Adobe Photoshop 4.0, and brightness and 
contrast were adjusted so that the images looked alike. Images with pixels in the gray scale 0 to 255 (from black to white) were then analyzed as described by Pastorino et al. (2003a). Images were converted from their gray-scale values to binary images in which gray pixels were converted to either white or black pixels by applying the threshold function of the software. In the original digital images, dark pixels corresponded to areas of the micrograph occupied by pockets that originally contained fat and/or serum, whereas light pixels corresponded to areas occupied by protein matrix. When thresholding, pixels having a gray value lower than the threshold level were converted to black pixels, whereas those having a gray value higher than the threshold level were converted to white pixels. A threshold level of 120 was found to provide a differentiation between dark and light areas as determined by visually matching the original and binary images. The proportions of black and white pixels, and the areas occupied by them were then determined by applying the histogram function of the software. Thus, the areas of cheese matrix occupied by fat/serum pockets (dark areas) and protein matrix (light areas) were determined.

\section{Cheese Functionality}

After $40 \mathrm{~d}$ of storage at $4^{\circ} \mathrm{C}$, cheese was removed from its packaging, blotted with paper towels, and reweighed. Melting was analyzed using the UW Meltmeter (University of Wisconsin-Madison, WI) as described by Wang et al. (1998). Duplicate cheese samples, $3 \mathrm{~cm}$ in diameter and $0.7 \mathrm{~cm}$ in height, were tested at $60^{\circ} \mathrm{C}$ with the height of cheese recorded every $0.2 \mathrm{~s}$ for $60 \mathrm{~s}$. Initial rate of flowing was defined as the rate $(\mathrm{mm} /$ s) at which cheese height decreased during the first 5.0 $\mathrm{s}$ of the test. Also, the final extent of cheese flow (cheese height) at $40.0 \mathrm{~s}$ was determined. Texture profile analysis was performed as described by Pastorino et al. (2003a). Thus, a two-bite compression test was run on an Instron 5542 (Canton, MA) with a $1.2-\mathrm{kg}$ static load cell (rating: $\pm 500 \mathrm{~N}$ ), $75 \%$ compression factor, and crosshead speed set at $20 \mathrm{~mm} / \mathrm{min}$. Samples, $20 \mathrm{~mm}$ long $\times$ $16 \mathrm{~mm}$ in diameter, were taken from the cheese immediately after removal from the refrigerator, and tested at approximately $5^{\circ} \mathrm{C}$. Hardness, cohesiveness, and adhesiveness were determined by analyzing the data according to Bourne (1978).

\section{Experimental Design and Statistical Analysis}

The experiment was conducted in triplicate as a completely randomized design. Three treatments, corresponding to number of injections (one, three, or five), along with a control, uninjected cheese, were considered in the experiment. Two cheese samples were analyzed for all variables except cheese weight, soluble and total calcium, and soluble nitrogen content, and their mean was considered for analysis of variance. For scanning electron microscopy, at least five cheese samples of uninjected cheese and cheese injected five times, from one replication, were observed under the microscope, and the digital image of five fields was analyzed. Thus, each field was considered a replicate for analysis. Statistical analysis (GLM and LSD) was performed using SAS (1999).

\section{RESULTS}

When cheese is high-pressure injected, injection sites are apparent immediately after injection, but they are usually no longer visible after a few days of refrigerated storage. This was the case in previous work, when water (Pastorino et al., 2003b) or a sodium chloride solution (Pastorino et al., 2003a) was injected into cheese. In contrast, when acidulant was injected, injection sites were still visible after $40 \mathrm{~d}$ of storage. The same phenomenon was also observed when calcium was injected into cheese (Pastorino et al., 2003b).

In addition to observing injection sites, after $40 \mathrm{~d}$ of refrigerated storage, white crystals were observed on the surface of cheese blocks injected three and five times; being more abundant in cheese blocks injected five times. The crystals tended to arrange in clover-like structures with a cross-section length of up to $6 \mathrm{~mm}$.

\section{Chemical Composition}

The moisture and fat content of the control, uninjected cheese was 34 and 30\%, respectively. Calcium content was $0.8 \%$ and sodium chloride $1.7 \%$.

Injecting a concentrated solution of glucono- $\delta$-lactone significantly decreased cheese $\mathrm{pH}(P<0.01)$. Each injection decreased the $\mathrm{pH}$ of cheese by 0.13 units in average, and after five injections cheese $\mathrm{pH}$ decreased from 5.3 in the control, uninjected cheese to 4.7 (Figure 1).

Acidulant injection into cheese promoted syneresis, and after refrigerated storage there was free serum inside the package of cheese blocks injected five times. After each injection, the cheese had been blotted, so the serum in the package was serum expelled from the cheese rather than residual injectant not incorporated into the cheese block. Thus, acidulant injection significantly affected the moisture content of cheese $(P<0.01)$, and after five injections moisture content decreased from $34 \%$ in the control cheese to $31 \%$ (Figure 2A). This is in agreement with previous observations in which decreased $\mathrm{pH}$ resulted in cheese with reduced moisture content (Taneya et al., 1992; Ramkumar et al., 1997; 


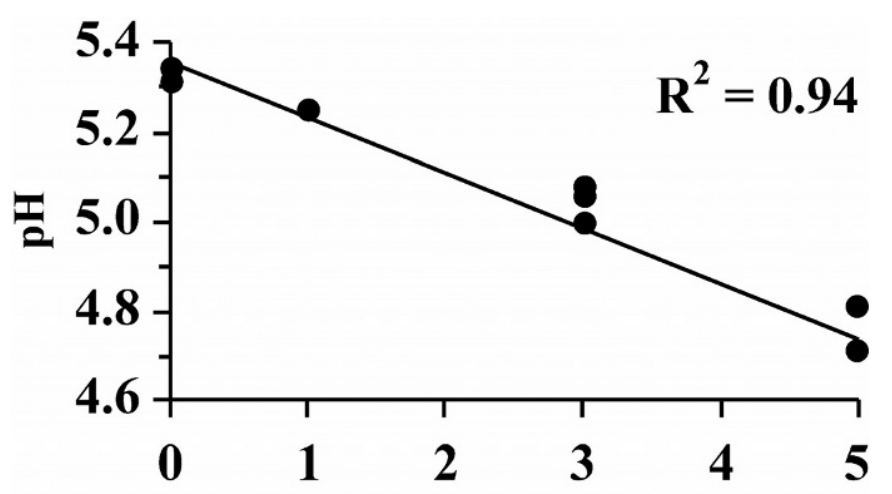

Number of injections

Figure 1. $\mathrm{pH}$ of Cheddar cheese injected with a glucono- $\delta$-lactone solution and then stored for $40 \mathrm{~d}$ at $4^{\circ} \mathrm{C}$. Successive injections performed $24 \mathrm{~h}$ apart.
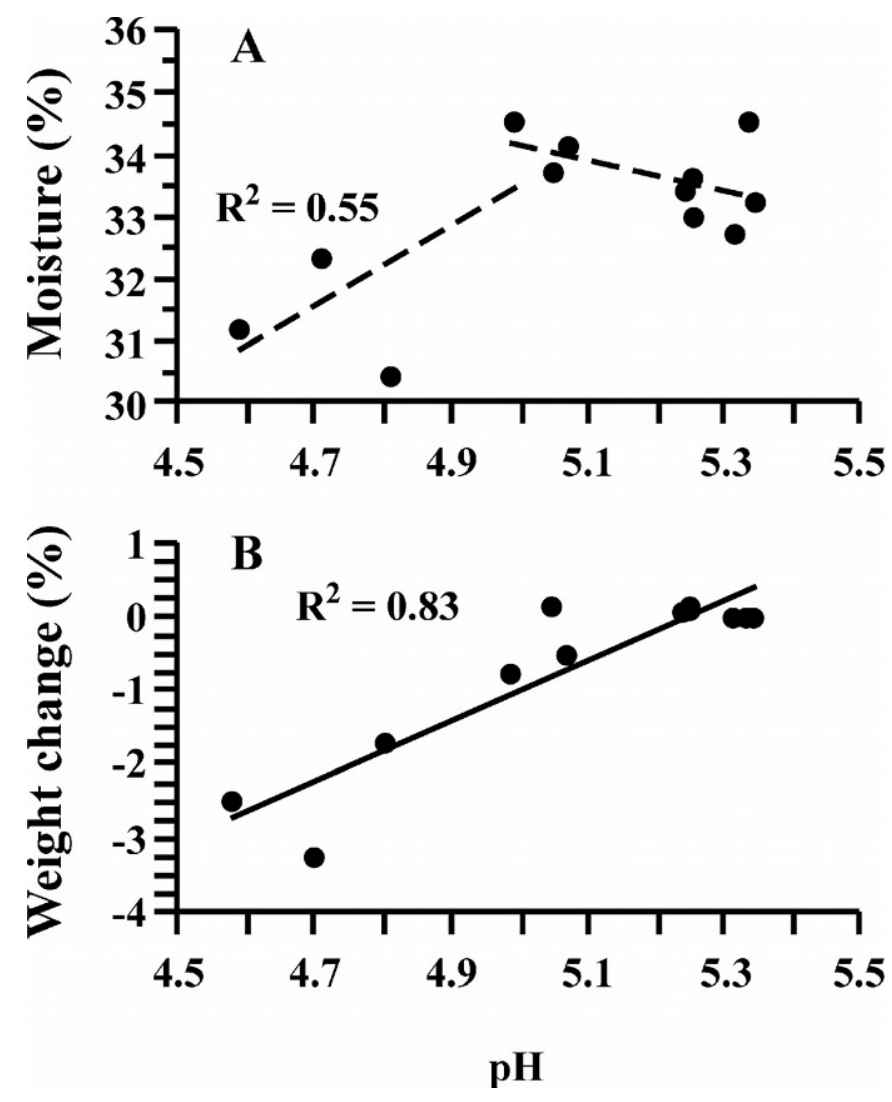

Figure 2. Moisture content (A) and weight change (B) of Cheddar cheese injected with a glucono- $\delta$-lactone solution and then stored for $40 \mathrm{~d}$ at $4^{\circ} \mathrm{C}$. Dashed, regression lines for cheeses with $\mathrm{pH} \geq 5.0$ and cheeses with $\mathrm{pH} \leq 5.0$. Coefficient of determination $\left(\mathrm{R}^{2}\right)$ shown when greater than 0.5 .
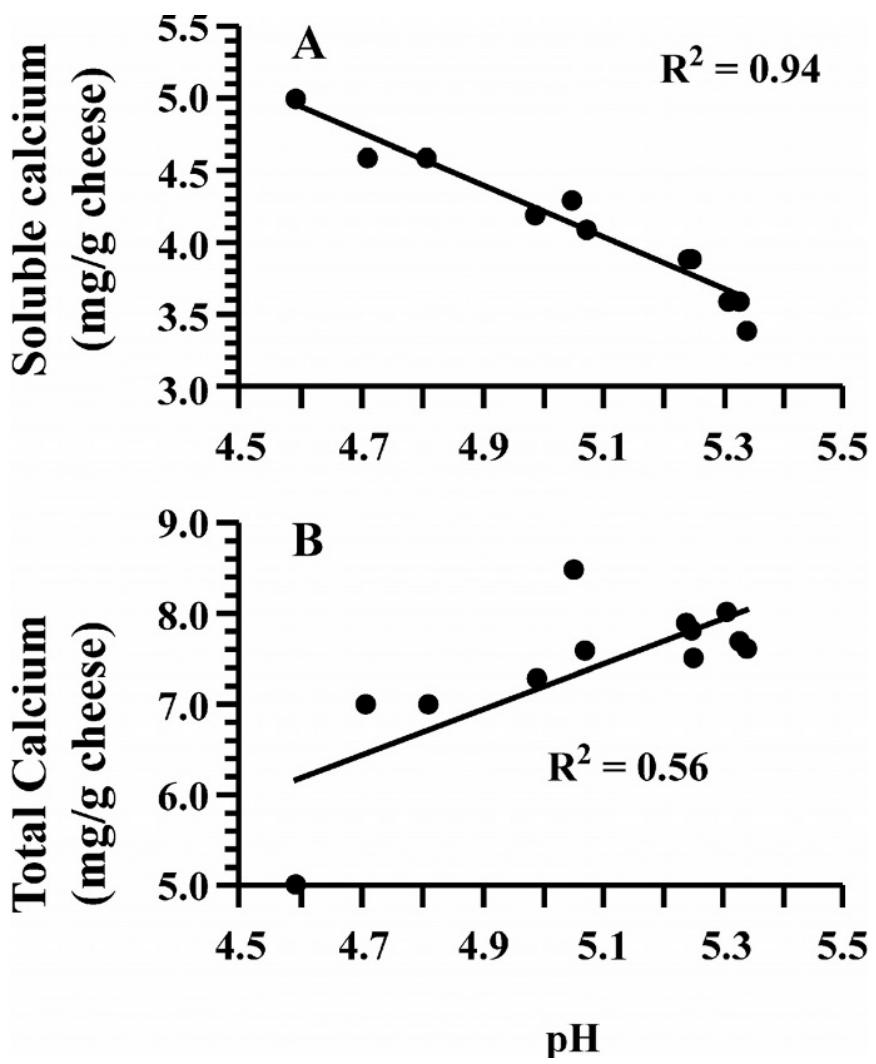

Figure 3. Soluble calcium (A) and total calcium content (B) of Cheddar cheese injected with a glucono- $\delta$-lactone solution and then stored for $40 \mathrm{~d}$ at $4^{\circ} \mathrm{C}$.

Watkinson et al., 2001). As a result of syneresis and moisture loss, cheese weight was significantly affected by acidulant injection $(P<0.01)$, and after five injections cheese weight decreased (Figure 2B).

Decreased cheese $\mathrm{pH}$ promoted significant calcium solubilization $(P<0.01)$, and soluble calcium content increased from $3.5 \mathrm{mg} / \mathrm{g}$ of cheese in the uninjected cheese to $4.7 \mathrm{mg} / \mathrm{g}$ of cheese after five injections (Figure $3 \mathrm{~A})$. Thus, the proportion of calcium in soluble form increased from $45 \%$ at $\mathrm{pH} 5.3$ to $75 \%$ at $\mathrm{pH}$ 4.7. This agrees with decreased $\mathrm{pH}$ of cheese curd promoting calcium solubilization from casein and into the serum as previously reported by Lawrence et al. (1983) and Ramkumar et al. (1997). In addition, the total calcium content of cheese seemed to be affected by acidulant injection $(P=0.07)$. Even though it remained unchanged after three injections, calcium content decreased after five injections (Figure 3B), which is in accordance with observations on syneresis and previous reports in which cheese with lower $\mathrm{pH}$ had decreased calcium content (Keller et al., 1974; Kiely et al., 1992).

The content of TCA-soluble nitrogen after $40 \mathrm{~d}$ of storage was significantly affected $(P<0.05)$ by injecting 


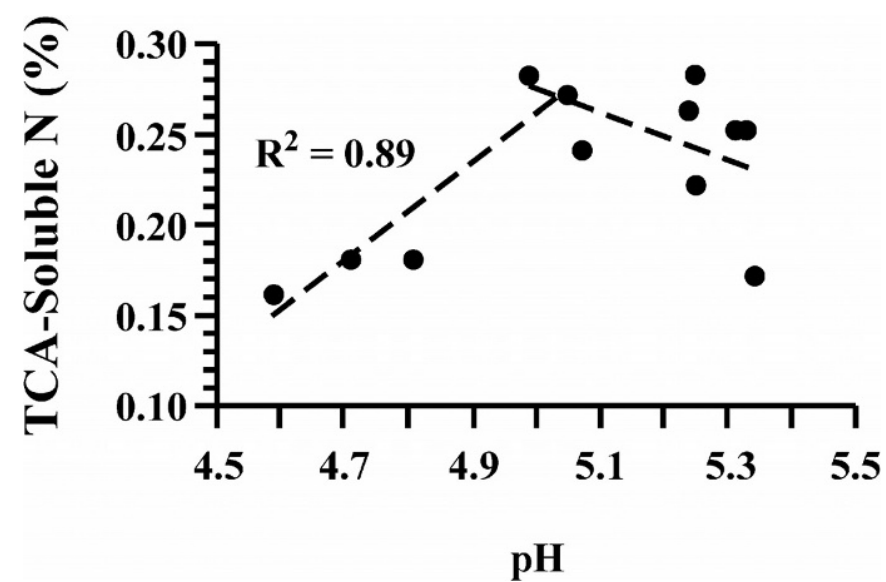

Figure 4. TCA-soluble nitrogen content of Cheddar cheese injected with a glucono- $\delta$-lactone solution and then stored for $40 \mathrm{~d}$ at $4^{\circ} \mathrm{C}$. Regression lines for cheeses with $\mathrm{pH} \geq 5.0$ and cheeses with $\mathrm{pH} \leq$ 5.0. Coefficient of determination $\left(R^{2}\right)$ shown when greater than 0.5 .

acidulant into cheese. Lowering cheese $\mathrm{pH}$ from 5.3 to 5.0 resulted in increased level of TCA-soluble nitrogen, but further lowering of $\mathrm{pH}$ to 4.7 resulted in decreased proteolysis (Figure 4). Similarly, the effect of lowered $\mathrm{pH}$ on decreased cheese proteolysis has been previously reported. Watkinson et al. (2001) observed decreased acid-soluble and water-soluble nitrogen in process cheese with lower $\mathrm{pH}$, and Creamer et al. (1988) reported decreased content of acid-soluble amino groups in Cheddar cheese with lower $\mathrm{pH}$.

\section{Cheese Microstructure}

The control, uninjected cheese ( $\mathrm{pH}$ 5.3) had a structure typical of a stirred/pressed-curd cheese, with protein matrix interspersed with areas that originally contained fat and/or serum (Figure 5A). The structure of acidulant-injected cheese ( $\mathrm{pH}$ 4.7) (Figure 5B) looked similar to that of the control cheese. Applying the threshold function of the software allowed us to obtain binary images of the original micrographs, and, thus, fat/serum pockets (black areas) were differentiated from the protein matrix (white areas). For the control cheese, the protein matrix occupied $82 \%$ of the cheese matrix area, with fat/serum pockets occupying the remaining $18 \%$. However, after five injections with acidulant, the area of cheese occupied by protein matrix significantly decreased $(P<0.05)$. Thus, the protein matrix occupied $80 \%$ of the cheese matrix area, with fat/serum pockets occupying the remaining $20 \%$.

\section{Cheese Functionality}

Acidulant injection significantly affected cheese hardness $(P<0.01)$, and, after three injections, the
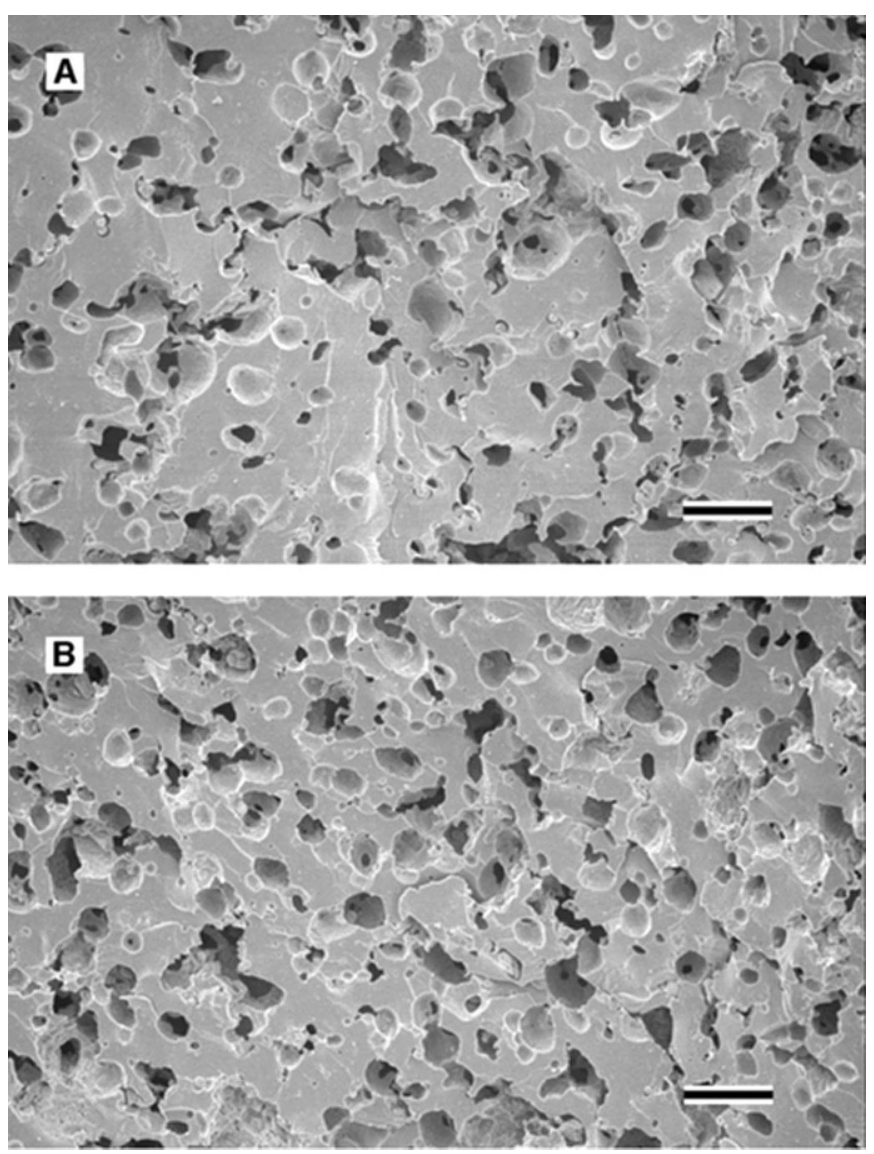

Figure 5. Scanning electron micrographs of Cheddar cheese after $40 \mathrm{~d}$ of storage at $4^{\circ} \mathrm{C}$. A: uninjected cheese ( $\mathrm{pH}$ 5.3); B: acidulantinjected cheese (five injections; $\mathrm{pH} 4.7$ ). $\mathrm{Bar}=10 \mu \mathrm{m}$.

cheese became more crumbly and had decreased hardness (Figure 6A). Similarly, it has been reported that cheese with lower $\mathrm{pH}$ normally becomes less firm and more crumbly, and hardness decreases (Marchesseau et al., 1997; Paulson et al., 1998; Ramkumar et al., 1998; Watkinson et al., 2001). The cohesiveness of cheese was also significantly affected by acidulant injection $(P<$ $0.05)$. Initially, cohesiveness was unaffected, but it decreased after five injections (Figure 6B). In contrast, $\mathrm{pH}$ had no effect on cheese adhesiveness, which is in agreement with the results reported by Watkinson et al. (2001).

During the melting test, the initial rate of cheese flow was significantly affected by cheese $\mathrm{pH}(P<0.01)$. After three injections ( $\mathrm{pH} 5.0$ ), decreased $\mathrm{pH}$ promoted the flow of cheese at a higher rate (Figure 7A). However, after five injections ( $\mathrm{pH} 4.7$ ), the initial rate of cheese flow was slower than the $\mathrm{pH}$ 5.0- or $\mathrm{pH}$ 5.3-cheese. The final extent of cheese flow, as determined by the height of the cheese sample after $40.0 \mathrm{~s}$, was also significantly affected by cheese $\mathrm{pH}(P<0.01)$, and after five injections 

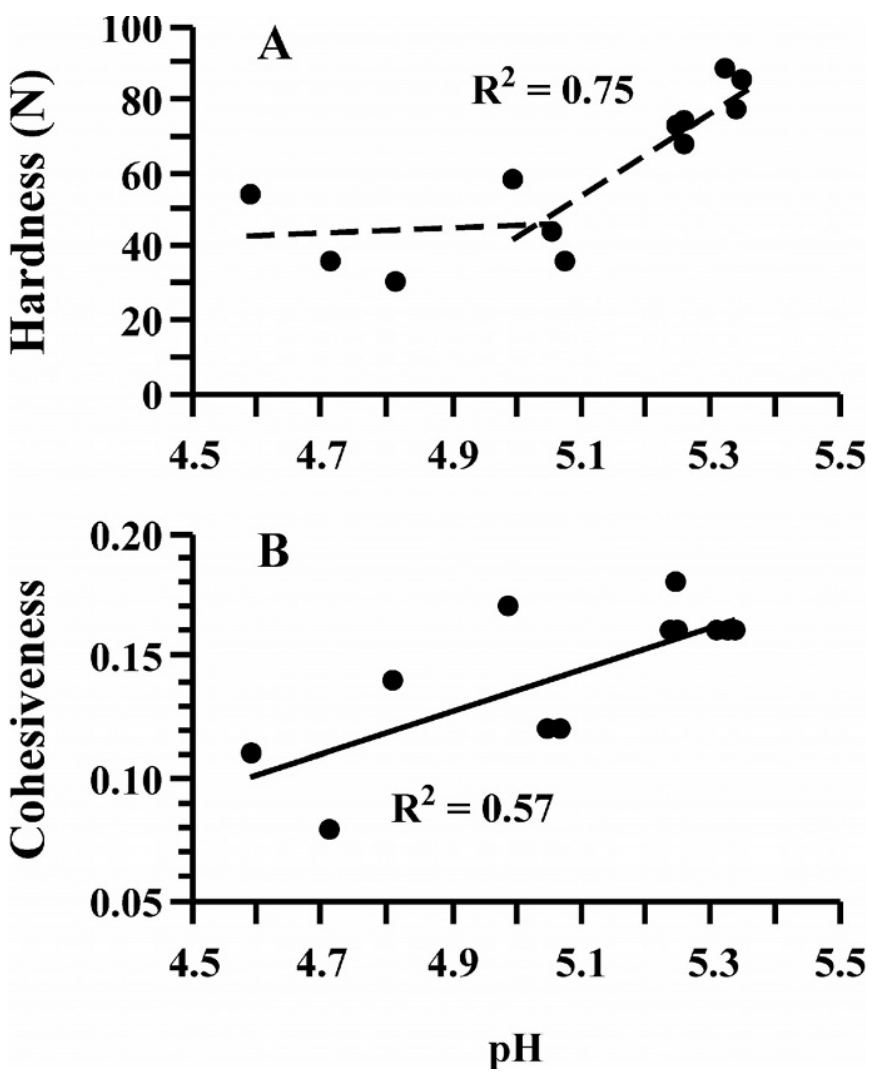

Figure 6. Hardness (A) and cohesiveness (B) of Cheddar cheese injected with a glucono- $\delta$-lactone solution and then stored for $40 \mathrm{~d}$ at $4^{\circ} \mathrm{C}$. Dashed, regression lines for cheeses with $\mathrm{pH} \geq 5.0$ and cheeses with $\mathrm{pH} \leq 5.0$. Coefficient of determination $\left(\mathrm{R}^{2}\right)$ shown when greater than 0.5 .

the cheese flowed to a lesser extent (Figure 7B). Similarly, Kindstedt et al. (2001) also observed that lowmoisture, part-skim Mozzarella lost the ability to flow and melt when $\mathrm{pH}$ was lower than 5.0.

\section{DISCUSSION}

\section{Chemical Composition}

Moisture. In previous work, injection of a concentrated solution of either calcium or sodium chloride resulted in syneresis and moisture losses of cheese, although for different reasons (Pastorino et al., 2003a, $2003 \mathrm{~b}$ ). When the dynamics of injecting a fluid into cheese are considered, the volume of serum in the cheese initially increases upon injection. However, pockets in the cheese matrix are already full; thus, unless the protein matrix expands to accommodate the extra fluid, excess serum will be expelled from within the cheese and syneresis will occur. If the solute portion of the injected fluid is preferentially retained in the
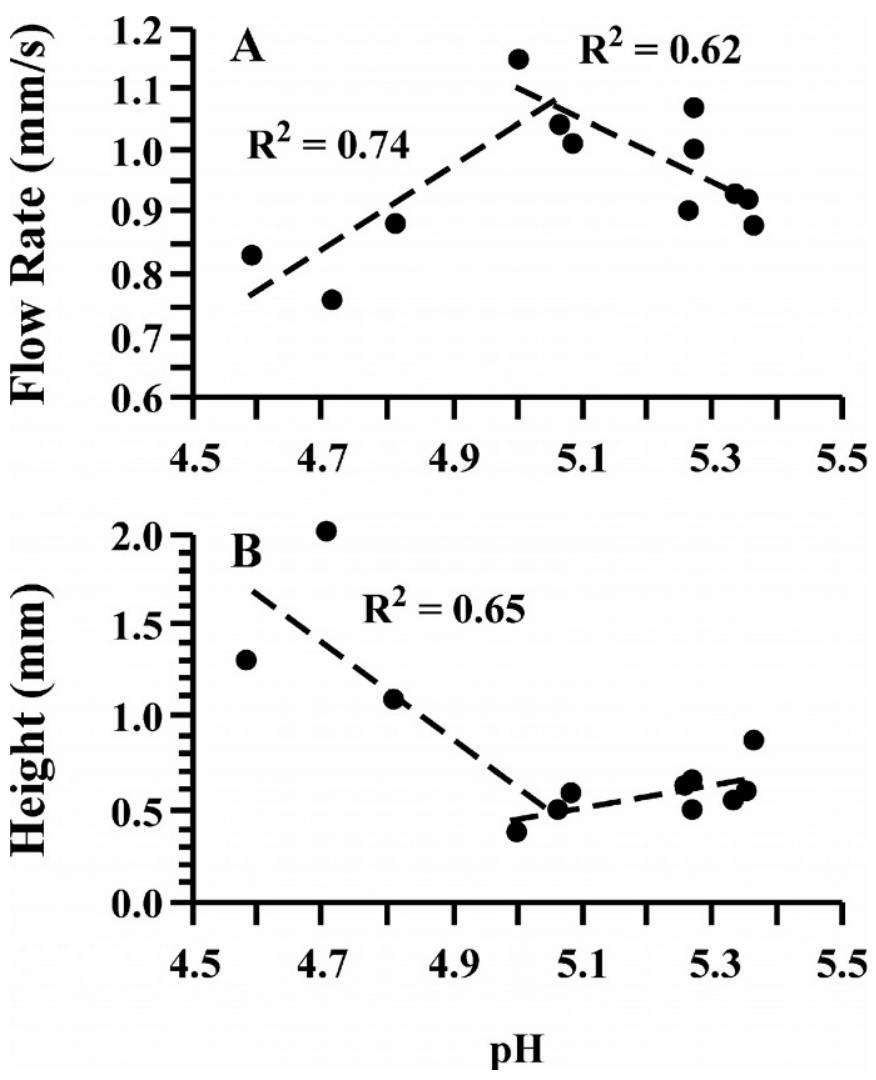

Figure 7. Initial flow rate (A) and melted cheese height (extent of flow) (B) of Cheddar cheese injected with a glucono- $\delta$-lactone solution and then stored for $40 \mathrm{~d}$ at $4^{\circ} \mathrm{C}$. Regression lines for cheeses with $\mathrm{pH} \geq 5.0$ and cheeses with $\mathrm{pH} \leq 5$.0. Coefficient of determination $\left(R^{2}\right)$ shown when greater than 0.5 .

cheese, then the moisture content of the cheese may actually decrease.

Injecting salt into cheese increases the hydration and water-holding capacity of the protein matrix, which results in increased moisture retention and expansion of the matrix (Pastorino et al., 2003a). However, the expansion of the protein matrix was insufficient to retain all the fluid and increased solid content, which resulted in syneresis during storage and a net reduction in the moisture content of cheese. In contrast, calcium injection promotes interaction between proteins that causes contraction of the protein matrix, decreased water-holding capacity of the matrix, release of water, and syneresis (Pastorino et al., 2003b). In the present experiment, lowering the $\mathrm{pH}$ of cheese resulted in syneresis (especially after five injections), possibly because of both increased volume of serum and contraction of the protein matrix.

At pH 5.2, there is increased solubilization of colloidal calcium phosphate and decreased interactions between proteins, which allows increased solvation of caseins (van Hooydonk et al., 1986). Thus, at pH 5.2, increased 
hydration of the protein matrix would be expected, leading to increased moisture content of cheese (Keller et al., 1974). However, lowering of $\mathrm{pH}$, especially below 5.0, would promote protein-to-protein interactions as the caseins approach their isoelectric point and electrostatic repulsions are minimized (Visser et al., 1986; Marchesseau et al., 1997). Thus, the ability of proteins to interact with water and the water-holding capacity of the protein matrix would decrease below $\mathrm{pH} 5.0$, which then results in increased syneresis and decreased moisture content of cheese.

Calcium. Decreasing the $\mathrm{pH}$ of milk causes dissociation of minerals, mainly calcium and phosphorous, from colloidal calcium phosphate into soluble ions and complexes (Keller et al., 1974; van Hooydonk et al., 1986; Visser et al., 1986; Dalgleish and Law, 1989; Lucey et al., 1996; Le Graët and Gaucheron, 1999). As a result, the content of soluble calcium in cheese increases as $\mathrm{pH}$ is lowered (Kindstedt et al., 2001; Watkinson et al., 2001). Such an inverse linear relationship between $\mathrm{pH}$ and soluble calcium content was observed in the present experiment, with the proportion of calcium in soluble form increasing from $45 \%$ at $\mathrm{pH} 5.3$ to $75 \%$ at $\mathrm{pH} 4.7$. Thus, after three injections ( $\mathrm{pH} 5.0$ ), the amount of bound calcium decreased from 17 to $14 \mathrm{mg} / \mathrm{g}$ of protein. Lowering the $\mathrm{pH}$ of cheese from 5.0 to 4.7 further decreased the amount of bound calcium, from 14 to $6 \mathrm{mg} /$ $\mathrm{g}$ of protein, and the amount of total calcium slightly decreased, presumably because of syneresis and loss of soluble calcium in the expelled serum.

Proteolysis. Lowering cheese $\mathrm{pH}$ from 5.3 to 5.0 resulted in increased content of TCA-soluble nitrogen in cheese after $40 \mathrm{~d}$ of refrigerated storage. Calcium solubilization would promote partial relaxation of proteinprotein interactions, which could enable proteolytic enzymes to better access sites for hydrolysis. However, lowering cheese $\mathrm{pH}$ from 5.0 to 4.7 resulted in less proteolysis occurring during cheese storage. This decrease in proteolysis is probably because of decreased microbial and enzymatic activities at lower $\mathrm{pH}$ (Creamer et al., 1988). In particular, lower cheese $\mathrm{pH}$ decreases the activity of plasmin, which may then result in decreased breakdown of $\beta$-casein (Watkinson et al., 2001).

\section{Cheese Microstructure}

The solubilization of minerals from caseins that is brought about by decreased $\mathrm{pH}$ at low temperature leads first to decreased interactions between proteins, and caseins normally dissociate from casein micelles (Roefs et al., 1985; van Hooydonk et al., 1986; Dalgleish and Law, 1988). Thus, lowering the $\mathrm{pH}$ of milk from 6.7 to 5.4 or 5.3 increases the solubility of caseins (Roefs et al., 1985) and leads to the presence of smaller casein aggregates (Visser et al., 1986). In cheese, at pH 5.3 or 5.2 , larger aggregates are observed in the protein matrix compared with cheeses with lower $\mathrm{pH}$ (e.g., $\mathrm{pH} 5.0$ [Hall and Creamer, 1972; Lawrence et al., 1983, 1987]). Thus, a model for the protein matrix of cheese is proposed that at $\mathrm{pH} 5.3$ is characterized by the presence of relatively large high-density protein aggregates, 10 to $12 \mathrm{~nm}$ in diameter, and by having a relatively welldefined structure in which protein strands can be identified (Figure 8A).

Further lowering of $\mathrm{pH}$ below 5.2 increases calcium solubilization and decreases electrostatic repulsions between proteins as the caseins approach their isoelectric point. As a result, casein aggregates in milk cluster together, thus increasing the heterogeneity of the system (Visser et al., 1986), and, at $\mathrm{pH}$ 5.0, the protein matrix of cheese has a less well-defined structure (Hall and Creamer, 1972; Taneya et al., 1992) with smaller protein aggregates (Hall and Creamer, 1972; Lawrence et al., 1983, 1987). This is represented in the model by a protein matrix that has smaller aggregates, 6 to 7 $\mathrm{nm}$ in diameter, which locate closer to one another, resulting in shorter protein strands and a less welldefined structure (Figure 8B).

Interactions between proteins significantly increase below pH 5.0 (van Vliet and Walstra, 1994), which results in the contraction of protein aggregates during the formation of milk gels (Visser et al., 1986), and below $\mathrm{pH} 5.0$ cheese is characterized by having protein aggregates of even smaller size (Hall and Creamer, 1972; Lawrence et al., 1983, 1987). Thus, at pH 4.7 the protein matrix in the model is characterized by the presence of high-density aggregates 2 to $4 \mathrm{~nm}$ in diameter that tend to cluster, making protein strands no longer visible, and decreasing the structural uniformity of the matrix (Figure 8C).

In agreement with the previous description, injecting acidulant into cheese caused a decrease in $\mathrm{pH}$ that after three injections ( $\mathrm{pH}$ 5.0) impaired protein-to-protein interactions due to calcium solubilization, but that significantly increased interactions between proteins after five injections ( $\mathrm{pH} 4.7$ ) because of decreased electrostatic repulsion. Thus, at $\mathrm{pH} 4.7$, the acid precipitation of the caseins overcame the opposing effect of calcium solubilization, and a net increase in protein-to-protein interactions caused contraction of the protein matrix.

\section{Cheese Functionality}

Hardness. Lowering the $\mathrm{pH}$ of cheese normally results in cheese with decreased hardness (Paulson et al., 1998; Watkinson et al., 2001). Thus, the cheese has less of a solid-like behavior (Ramkumar et al., 1998) and it 


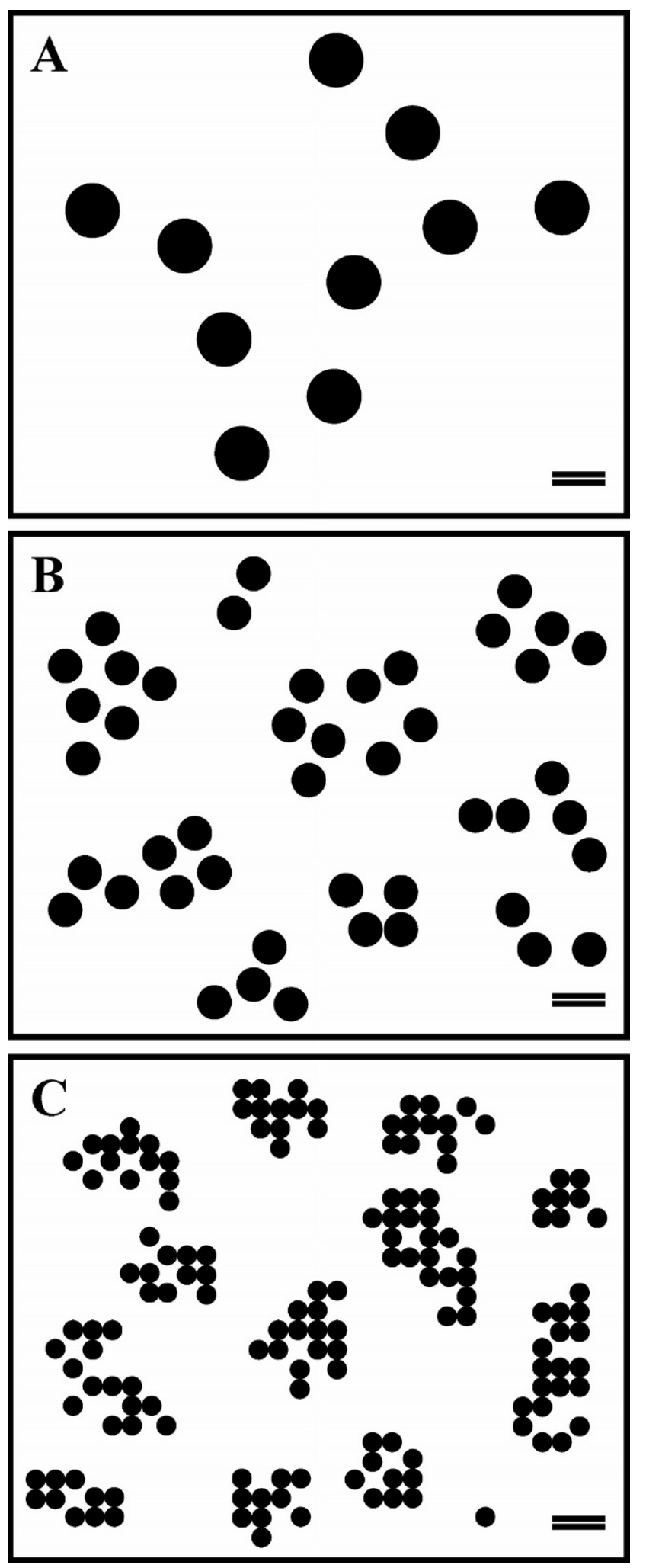

Figure 8. Diagram modeling the protein matrix of Cheddar cheese at $\mathrm{A}: \mathrm{pH} 5.3$ (uninjected); $\mathrm{B}: \mathrm{pH} 5.0$ (three injections); and C: $\mathrm{pH} 4.7$ (five injections). Dark circles represent high-density protein aggregates. $\mathrm{Bar}=10 \mathrm{~nm}$. may become more elastic (Keller et al., 1974). In contrast, Creamer et al. (1988) observed no significant correlation between the $\mathrm{pH}$ and hardness of Cheddar cheese ( $\mathrm{pH}$ range of 5.3 to 4.9 ). However, when comparing cheeses with similar calcium content $(0.91$ and $0.95 \%$ ) but different $\mathrm{pH}$ (4.9 and 5.1), cheese with lower $\mathrm{pH}$ had decreased hardness. Also, in their study, modifying cheese $\mathrm{pH}$ resulted in changes in other chemical parameters of cheese. Thus, the effect of $\mathrm{pH}$ on cheese hardness may depend on the range of $\mathrm{pH}$ values considered, and it may be confounded by changes in other chemical parameters of the cheese.

Watkinson et al. (2001) observed processed cheese with lower pH, from 6.2 to 5.2 , to have decreased firmness and to become more crumbly. In their study, lower $\mathrm{pH}$ was accompanied by decreased moisture and increased soluble calcium content of cheese, and by changes in the pattern and extent of proteolysis in cheese. They suggested, however, that the effect of $\mathrm{pH}$ on rheological and fracture properties of cheese mainly resulted from changes in calcium-mediated protein interactions as a result of calcium solubilization. In addition, increased structural uniformity of the matrix has been observed to increase cheese firmness (Rayan et al., 1980), and Marchesseau et al. (1997) observed process cheese to have a less homogeneous and dense protein network at $\mathrm{pH} 5.2$ compared with $\mathrm{pH}$ 5.7. Thus, they suggested that decreased structural uniformity could not allow for even distribution of stress, which would then result in cheese of lower $\mathrm{pH}$ (5.2) having decreased firmness.

The results of the present study are in agreement with previous observations in which lowering the $\mathrm{pH}$ of cheese resulted in decreased hardness. In particular, lowering the $\mathrm{pH}$ of cheese from 5.3 to 5.0 would affect cheese hardness by affecting calcium-mediated protein interactions through changes in the distribution of calcium between its soluble and insoluble forms, which is in agreement with the proposition of Watkinson et al. (2001). Thus, after three injections, decreased $\mathrm{pH}$ caused solubilization of calcium from casein aggregates that decreased interactions between proteins and that probably facilitated structural rearrangements in the protein matrix. Decreased protein-to-protein interactions resulted then in the weakening of the protein matrix that led to decreased hardness of cheese, an effect that can be better understood with insight from polymer and materials science.

From a materials science point of view, cheese could be considered a composite material in which two main structural components are recognized: protein and fat. Protein is the polymeric material that makes up the structure of the matrix, whereas fat participates either as a filler (nonhomogenized milk) or as a copolymer 
(homogenized milk). The strength of a composite material depends on its composition, the properties of the polymeric and filler material, and on the nature and extent of their interactions or cross-linking (Calvert, 1997). Also, orientation of the polymeric material and structural regularity increases the strength and toughness of the material. In the present experiment, after three injections with acidulant solution, the gross composition of cheese was unchanged, and no major changes in the state of fat would be expected. Therefore, changes in the state of the polymeric material, i.e., protein, and its interactions would account for changes in textural properties of cheese.

The strength of a material can be enhanced by increasing the molecular weight of the polymeric constituent, the chain length, the extent of cross-linking, and the orientation or structural regularity of the material; all of which improve the transfer of load between polymeric units (Calvert, 1997). Calcium promotes protein interactions (Pastorino et al., 2003b), probably through calcium bridging and charge neutralization. Hence, the solubilization of calcium from casein would decrease the extent of interaction or cross-linking between the polymeric units, i.e., protein aggregates. This would then impair the transfer of stress, thus decreasing the hardness of cheese. As described in the proposed model for the protein matrix of cheese, it is possible that decreased interaction between proteins resulted also in decreased size of protein aggregates and/or decreased length of protein strands in the matrix (Figure 8B), which would further decrease the hardness of cheese. In addition, decreased interaction between proteins could also influence the structural regularity of the protein matrix, which could in turn affect cheese hardness as previously suggested by Marchesseau et al. (1997).

In contrast to the observed decreased hardness of cheese when $\mathrm{pH}$ decreased from 5.3 to 5.0, further lowering of $\mathrm{pH}$ from 5.0 to 4.7 had no effect on cheese hardness. Even though the cheese had decreased calcium and moisture content, no further decrease in cheese hardness was observed after five injections $(\mathrm{pH}$ 4.7). It is possible that as the caseins approached their isoelectric point, increased protein-to-protein interactions compensated for the decreased calcium and moisture content of cheese that would make the cheese less hard and more crumbly. Applying the same principles from materials science, the acid precipitation of proteins could lead to increased interaction between neighboring protein aggregates, which now locate closer to one another (Figure 8C). This would then facilitate the transfer of stress between these polymeric units, thus promoting increased hardness to an extent that possibly compensated for the opposing effect of decreased calcium and moisture content of cheese.
Cohesiveness. In accordance with previous work (Pastorino et al., 2003a, 2003b), altered protein interactions affected cheese cohesiveness. However, cheese cohesiveness significantly decreased only after five injections, when the cheese had decreased moisture and calcium content. Both decreased moisture and calcium content have been associated with decreased cohesiveness of cheese (Pastorino et al., 2003a, 2003b), and moisture content may per se affect cheese cohesiveness (Tunick et al., 1991). Thus, the effect of $\mathrm{pH}$ on cohesiveness was confounded with decreased calcium and moisture content of cheese. As previously proposed (Pastorino et al., 2003a), it is possible that decreased long-range protein interactions caused the cheese to become less cohesive and elastic, and more crumbly. Even though interactions between proteins were favored at $\mathrm{pH} 4.7$, they probably involved neighboring aggregates and did not extend considerably throughout the matrix (Figure 8C). This would be in agreement with the observed decreased hardness of cheese, as less extended, shortrange protein interactions would result in decreased transfer of stress between polymeric units.

Flow. The effect of $\mathrm{pH}$ on cheese flow was also related to altered protein interactions. When $\mathrm{pH}$ decreased from 5.3 to 5.0, calcium was solubilized from caseins and the amount of bound calcium decreased. This resulted in cheese with increased initial rate of flow. Calcium is a strong promoter of protein-to-protein interactions, and its solubilization would decrease interactions between proteins, thus facilitating the initial flow of cheese. However, after three injections, and even though calcium had been solubilized, the total calcium content remained the same, and decreased $\mathrm{pH}$ had no effect on the final extent of cheese flow. Similarly, Paulson et al. (1998) observed no effect of $\mathrm{pH}$, in the range of 5.8 to 5.3, on the melting of nonfat Mozzarella cheese whose calcium content remained unchanged.

In contrast, lowering $\mathrm{pH}$ from 5.0 to 4.7 decreased both the initial rate and the final extent of cheese flow. At $\mathrm{pH}$ 4.7, the cheese had increased content of soluble calcium, and decreased amount of bound and total calcium, which would result in decreased protein-to-protein interactions. However, after five injections, the decrease in cheese flow and the contraction of the protein matrix were indications of increased interactions between proteins. As the $\mathrm{pH}$ of cheese decreases from 5.0 to 4.7 , caseins approach their isoelectric point and electrostatic interactions decrease, which would favor protein-to-protein interactions. Thus, below $\mathrm{pH}$ 5.0, the acid precipitation of caseins overcame the opposing effect of calcium solubilization and lower calcium content, resulting in a net increase in protein-to-protein interactions that significantly impaired the flow of cheese. 


\section{CONCLUSIONS}

Lowering the $\mathrm{pH}$ of Cheddar cheese by injecting an acidulant solution alters protein interactions, which then affects cheese functionality. Decreased pH not only promotes calcium solubilization and decreased calcium content of cheese, which impair interactions between proteins, but it also leads at low $\mathrm{pH}$ to isoelectric precipitation of caseins, which favors interactions between proteins. At low levels of acidulant injection, calcium solubilization is the predominant factor, and interactions between proteins decrease. Thus, the content of bound calcium would direct cheese functionality when the $\mathrm{pH}$ of cheese is above 5.0. In contrast, at high levels, acidulant injection promotes protein-to-protein interactions as the caseins approach their isoelectric point. Thus, at $\mathrm{pH}$ values below 5.0, the acid precipitation of caseins overcomes the opposing effect caused by increased calcium solubilization and decreased calcium content of cheese, and there is a net increase of proteinto-protein interactions.

\section{ACKNOWLEDGMENTS}

This research was funded by Dairy Management Incorporated and the Utah Agricultural Experiment Station.

\section{REFERENCES}

Association of Official Analytical Chemists. 1990. Official Methods of Analysis. 15th ed. AOAC, Arlington, VA.

Bourne, M. C. 1978. Texture profile analysis. Food Technol. 32:62-66.

Calvert, P. 1997. Protein composite materials. Chapter 6 in ProteinBased Materials. K. McGrath and D. Kaplan, ed. Birkhäuser, Boston, MA.

Creamer, L. K., J. Gilles, and R. C. Lawrence. 1988. Effect of pH on the texture of Cheddar and Colby cheese. N.Z. J. Dairy Sci. Technol. 23:23-35.

Dalgleish, D. G., and A. J. R. Law. 1988. pH-Induced dissociation of bovine casein micelles. I. Analysis of liberated caseins. J. Dairy Res. 55:529-538.

Dalgleish, D. G., and A. J. R. Law. 1989. pH-Induced dissociation of bovine casein micelles. II. Mineral solubilization and its relation to casein release. J. Dairy Res. 56:727-735.

Hall, D. M., and L. K. Creamer. 1972. A study of the sub-microscopic structure of Cheddar, Cheshire and Gouda cheese by electron microscopy. N.Z. J. Dairy Sci. Technol. 7:95-102.

Keller, B., N. F. Olson, and T. Richardson. 1974. Mineral retention and rheological properties of Mozzarella cheese made by direct acidification. J. Dairy Sci. 57:174-180.

Kiely, L. J., P. S. Kindstedt, G. M. Hendricks, J. E. Levis, J. J. Yun, and D. M. Barbano. 1992. Effect of draw pH on the development of curd structure during the manufacture of Mozzarella cheese. Food Struct. 11:217-224

Kindstedt, P. S., A. Zielinski, M. Almena-Aliste, and C. Ge. 2001. A post-manufacture method to evaluate the effect of $\mathrm{pH}$ on mozzarella cheese characteristics. Aust. J. Dairy Technol. 56:202-207.

Lawrence, R. C., L. K. Creamer, and J. Gilles. 1987. Texture development during cheese ripening. J. Dairy Sci. 70:1748-1760.

Lawrence, R. C., J. Gilles, and L. K. Creamer. 1983. The relationship between cheese texture and flavour. N.Z. J. Dairy Sci. Technol. 18:175-190.
Le Graët, Y., and F. Gaucheron. 1999. pH-Induced solubilization of minerals from casein micelles: influence of casein concentration and ionic strength. J. Dairy Res. 66:215-224.

Lucey, J. A., and P. F. Fox. 1993. Importance of calcium and phosphate in cheese manufacture: A review. J. Dairy Sci. 76:1714-1724.

Lucey, J. A., C. Gorry, B. O'Kennedy, M. Kalab, R. Tan-Kinita, and P. F. Fox. 1996. Effect of acidification and neutralization of milk on some physico-chemical properties of casein micelles. Int. Dairy J. 6:257-272.

Marchesseau, S., E. Gastaldi, A. Lagaude, and J.-L. Cuq. 1997. Influence of $\mathrm{pH}$ on protein interactions of process cheese. J. Dairy Sci. 80:1483-1489.

McManus, W. R., D. J. McMahon, and C. J. Oberg. 1993. High resolution scanning electron microscopy of milk products: A new sample preparation procedure. Food Struct. 12:475-482.

Pastorino, A. J. 2002. Effect of chemical parameters on structurefunction relationships of cheese. Ph.D. Diss., Utah State University, Logan.

Pastorino, A. J., C. L. Hansen, and D. J. McMahon. 2003a. Effect of salt on structure-function relationships of cheese. J. Dairy Sci. 86:60-69.

Pastorino, A. J., N. P. Ricks, C. L. Hansen, and D. J. McMahon. 2003b. Effect of calcium and water injection on structure-function relationships of cheese. J. Dairy Sci. 86:105-113.

Paulson, B. M., D. J. McMahon, and C. J. Oberg. 1998. Influence of $\mathrm{pH}$, calcium, and moisture on physical properties of nonfat Mozzarella cheese. J. Dairy Sci. 81(Suppl. 1):13. (Abstr.)

Ramkumar, C., O. H. Campanella, P. J. Watkinson, R. J. Bennett, and L. K. Creamer. 1998. The effects of pH and time on rheological changes during early cheese maturation. J. Texture Stud. 29:633-644.

Ramkumar, C., L. K. Creamer, K. A. Johnston, and R. J. Bennett. 1997. Effect of $\mathrm{pH}$ and time on the quantity of readily available water within fresh cheese curd. J. Dairy Res. 64:123-134.

Rayan, A. A., M. Kalab, and C. A. Ernstrom. 1980. Microstructure and rheology of process cheese. Scanning Electron Microsc. 3:635-643.

Richardson, G. H., ed. 1985. Page 351 in Standard Methods for the Examination of Dairy Products. 15th ed. Am. Publ. Health Assoc., Washington, DC.

Roefs, S. P. F. M., P. Walstra, D. G. Dalgleish, and D. S. Horne. 1985. Preliminary note on the change in casein micelles caused by acidification. Neth. Milk Dairy J. 39:119-122.

SAS User's Guide: Statistics, Version 8.2. Edition 1999. SAS Inst., Inc., Cary, NC.

Taneya, S., T. Izutsu, T. Kimura, and T. Shioya. 1992. Structure and rheology of string cheese. Food Struct. 11:61-71.

Tunick, M. H., K. L. Mackey, P. W. Smith, and V. H. Holsinger. 1991. Effects of composition and storage on the texture of Mozzarella cheese. Neth. Milk Dairy J. 45:117-125.

US Environmental Protection Agency. 1992. Inductively coupled plasma-atomic emission spectroscopy. Method 6010a (Revision 1) in Test Methods for Evaluating Solid Waste, Vol. 1A: Laboratory Manual Physical/Chemical Methods. Office of Solid Waste and Emergency Response. US Environ. Prot. Agency, Washington DC.

van Hooydonk, A. C. M., H. G. Hagedoorn, and I. J. Boerrigter. 1986 pH-Induced physico-chemical changes of casein micelles in milk and their effect on renneting. 1. Effect of acidification on physicochemical properties. Neth. Milk Dairy J. 40:281-196.

van Vliet, T., and P. Walstra. 1994. Water in casein gels; how to get it out or keep it in. J. Food Eng. 22:75-88.

Visser, J., A. Minihan, P. Smits, S. B. Tjan, and I. Heertje. 1986. Effects of $\mathrm{pH}$ and temperature on the milk salt system. Neth. Milk Dairy J. 40:351-368.

Wang, Y.-C., K. Muthukumarappan, M. M. Ak, and S. Gunasekaran. 1998. A device for evaluating melt/flow characteristics of cheeses. J. Texture Stud. 29:43-55.

Watkinson, P., C. Coker, R. Crawford, C. Dodds, K. Johnston, A. McKenna, and N. White. 2001. Effect of cheese $\mathrm{pH}$ and ripening time on model cheese textural properties and proteolysis. Int. Dairy J. 11:455-464. 